\title{
LEGISLASI HUKUM KELUARGA ISLAM BERDASARKAN KOMPILASI HUKUM ISLAM
}

\author{
Ismail Keri \\ Sekolah Tinggi Agama Islam Negeri Watampone, Bone, Indonesia \\ e-mail: ismail_keri@gmail.com
}

\begin{abstract}
Islamic Family Law consists of fundamental nationalities that always live and develop along with the development of society in the life of the nation. The configuration of national life interests is an instrument contested by the nation's components in these interests in the path of the state constitution, thus gaining a place of legitimacy in the process of constructing a national legal order. The history of national legal legislation has included the Compilation of Islamic Law as one of the country's alignments with the process of Islamic family law into National law. At the same time, the recovery of the development of Islamic Family Law is increasingly lively as the process of finding answers to Islamic problems in the archipelago's insight, how: Compilation of Islamic Law accommodates changes in the application of Islamic family law in Indonesia?

The description that can be obtained in this study shows that based on the history of beginning, the Compilation of Islamic Law is present as meeting the needs of the Islamic community as well as filling in the gaps that occur in the Religious Courts whose authority is regulated in Law No. 7 of 1989. However, in its journey, a number of studies and studies explained that the Compilation of Islamic Law contained a variety of potential criticisms, in which the Compilation of Islamic Law was deemed to be no longer sufficient in resolving various complex complexity problems. Therefore it is necessary to reconstruct the Compilation of Islamic Law by paying attention to the principles of equality (al-muswah), brotherhood (al-ikhâ'), and justice (al-'adl), as well as basic ideas for the formation of civil society, such as pluralism, gender equality, Human rights, democracy, and egalitarianism, so that the needs of Islamic family law can be fulfilled in several such as Constitutional aspects, Content aspects (Material / Content and Ideas), Aspects of Islamic Law Enforcement (rule of law) in the Indonesianness frame.
\end{abstract}

Keywords: Konfigurasi, Hukum Keluarga Islam, al-musâwah, al-ikhâ', al-'adl, pluralisme, dan egalitarianisme

\section{Pendahuluan}

Tidak dapat dipungkiri bahwa hukum merupakan instrumentasi keputusan politik, sehingga pembentukan hukum akan mencerminkan konfigurasi kekuatan dan kepentingan politik. Dalam aktualisasi kekuatan dan kepentingan politik ini terkadang terjadi benturan antara kepentingan fragmatisme dengan kepentingan yang bersifat permanen dan berpihak pada kemaslahatan umat manusia. Pada satu sisi, kepentingan fragmatisme akan cenderung mengabaikan nilai-nilai yang tumbuh dan berkembang di tengah masyarakat, dan di sisi lain kepentingan yang bersifat permanen 'termarginal' oleh isu-isu modernisasi, globalisasi dan memetakannya ke dalam watak kehidupan tradisional yang dikonotasikan dengan 'ketinggalan zaman'. Padahal keduanya dapat diintegrasikan dalam satu pola yang saling melengkapi dan berkontribusi. Artinya, 
kepentingan nilai-nilai ideologi yang hidup dan berkembang di tengah masyarakat dapat dikonfigurasi dengan kepentingan fragmatisme kekuatan politik.

Perbedaan mendasar antara hukum positif dengan hukum Islam adalah bahwa hukum positif merupakan pernyataan kehendak manusia yang berhimpun dalam wadah bernama negara sehingga kepentingan fragmatis tidak dapat terelakkan. Sedangkan hukum Islam merupakan hukum ketuhanan, sehingga nilai-nilai ideologi yang hidup dan berkembang di tengah masyarakat akan senantiasa mendapat ruang dan tempat untuk dikembangkan dan dilestarikan. Di negara-negara di mana Islam berpengaruh kuat, hukumnya juga akan banyak dipengaruhi oleh hukum Islam. Semula di dunia Islam, banyak persesuaian antara syar'i dan qanun. Ketegangan antara keduanya muncul akibat pengaruh Barat melalui kolonialismenya, yang mengakibatkan penggantian hukum di berbagai negara Muslim dengan hukum Eropa. Ketika masyarakat muslim berkesempatan membina hukumnya sendiri, mereka kembali menjadikan hukum Islam sebagai sumber penting legislasi. Demikian pula adanya yang terjadi dalam lintas sejarah legislasi hukum Islam di Indonesia.

Di Indonesia, agama dan negara adalah dua entitas yang berbeda, dan masingmasing memiliki otonominya sendiri, di mana ada wilayah yang sepenuhnya "milik" agama, negara tidak mungkin memasukinya dan ada pula wilayah yang sepenuhnya menjadi kompetensi negara, maka agama tidak dapat ikut di dalamnya. Dalam lintas sejarah pembangunan hukum Islam di Indonesia terukir konfigurasi yang saling menunjang antara kewenangan negara dengan ruang lingkup agama Islam, sehingga pola ini menjadi 'keran' yang membuka jalan untuk mengalirnya proses legislasi hukum Islam di Indonesia, seperti masalah perkawinan, kewarisan, dan perwakafan sebagaimana yang dibukukan dalam Kompilasi Hukum Islam (KHI), serta beberapa peraturan perundangundangan lainnya. ${ }^{1}$

Adanya persinggungan antara 'kepentingan negara dengan kewenangan Islam' serta ' kepentingan Islam dengan kewenangan negara' membuka mata umat muslim Indonesia bahwa sesungguhnya masyarakat Islam "beragama dalam berbangsa" dan "berbangsa dalam beragama". Dengan demikian, umat Islam harus menyadari dengan konkrit bahwa Islam tumbuh dan berkembang dari darah dan dagingnya sejarah yang aktual dan tidak lepas dari tangung jawab negara di dalamnya. Dalam konteks memahami kenyataan pola pembentukan hukum Islam di Indonesia khusunya proses penyusunan KHI, umat Islam harus menerima produksi sejarah yang melukiskan bahwa di dalam proses pembukuan KHI tersebut banyak terjadi perbedaan dan bahkan terkadang pertentangan antara ulama yang telah terkontaminasi dengan modernisasi dengan ulamaulama tradisional yang masih berpegang teguh pada pemikiran klasik yang bersumber dari kitab fikih ulama terdahulu. Kondisi tersebut harus diterima sebagai sebuah kenyataan, sehingga pada gilirannya generasi muslim akan tetap bercermin pada nilainilai perbedaan tersebut secara terukur dan terkontrol. Demikian pula keadaan tersebut menjadi tolak ukur dalam proses reintepretasi serta reaktualisasi norma-norma agama yang telah dibukukan dalam bentuk hukum Islam Formal seperti KHI. Oleh karena itu, proses reintepretasi serta reaktualisasi norma-norma hukum Islam melalui studi kritis maupun kajian akademik berdasarkan nilai-nilai yang tumbuh dan berkembang dalam masyarakat Islam dengan tetap berpegang teguh pada patron nash dan tidak menunjukkan pada kehendak yang ' kebablasan'.

1 Lihat, Mahsun Fuad, Hukum Islam Indonesia - Dari Nalar Partispatoris Hingga Emansipatoris, (Cet. 1 ; LkiS : Yogyakarta, 2005), h. 3 - 4. 
Dalam sejarah keberadaannya, KHI disusun dan dirumuskan untuk mengisi kekosongan hukum materil yang diberlakukan pada pengadilan dalam lingkungan peradilan agama. Dengan diberlakukannya KHI, secara yuridis hukum Islam di bidang perkawinan, kewarisan dan perwakafan menjadi hukum positif tertulis dalam sistem hukum nasional (Tata hukum Indonesia). KHI menjadi dasar untuk pengambilan keputusan hukum terhadap perkara-perkara yang diajukan ke pengadilan dalam lingkungan peradilan agama. ${ }^{2}$ Harus pula diakui bahwa keberadaan KHI di Indonesia di samping memiliki segi positif juga memunculkan problematka tersendiri, di mana usaha pemerintah Indonesia mengantar substansi hukum Islam yang sakralistis ke dalam KHI ternyata masih berhadapan dengan anggapan desakralisasi kitab fikih melalui instrumen peraturan perunbndang-undangan, yaitu KHI. ${ }^{3}$ Di samping itu, keberadaan KHI yang hanya dilegitimasi dalam bentuk Instruksi Presiden (Inpres ) membawa permasalahan tersendiri dalam sistem perundang-undangan di Indonesia, walaupun dalam prakteknya para hakim pengadilan agama menggunakan KHI sebagai salah satu dasar hukum dalam menyelesaikan perkara-perkara yang diajukan ke lingkungan peradilan agama, tanpa dengan mempedulikan bahwa KHI itu adalah hanya berupa Instruksi Presiden (Inpres).

Berdasarkan uraian di atas, maka dapat dirumuskan masalah pokok dalam tulisan ini yaitu bagaimana pelaksanaan legislasi hukum Islam di bidang hukum keluarga di Indonesia?. Untuk memberikan gambaran kajian ini secara rinci, maka masalah pokok tersebut akan diuraikan dalam beberapa sub masalah sebagai yaitu 1) Bagaimana sejarah dan dinamika legislasi Hukum Islam berdasarkan KHI di Indonesia ? dan 2) Bagaimana penerapan KHI dalam perspektif pembangunan hukum Islam kontemporer (aspek-aspek kekinian) di Indonesia ?

Kajian tentang legislasi hukum Islam di Indonesia merupakan salah satu bagian penting yang terintegrasi dalam memahami dinamika pembangunan hukum dan studi tentang efektifitas pelaksanaan peraturan perundang-undangan yang berlaku di tengah masyarakat Indonesia. Sementara itu, KHI adalah salah satu produk peraturan perundangundangan yang secara konstitusional mengikat seluruh masyarakat Indonesia yang beragama Islam, sehingga kajian tentang KHI dan dinamika penerapannya akan senantiasa penting adanya di mana berseiringan dengan dinamika kehidupan umat Islam di Indonesia. Jika direfleksi berdasarkan histori kehadiran KHI di Indonesia, maka aspekaspek muatan KHI akan menjadi berbincangan pada setiap sisi pembangunan hukum islam di Indonesia dan dari waktu ke waktu akan berproses secara alamiah sesuai dengan peradaban masyarakat Islam Indonesia. Hal ini menunjukkan bahwa kajian tentang legislasi hukum Islam dalam perspektif pembangunan hukum Islam yang kekinian akan memberikan kontribusi terhadap perkembangan aktualisasi nilai-nilai islam yang bersifat adaptatif. Selain itu, kajian tentang legislasi hukum islam khususnya melalui produk KHI memiliki makna penting dalam dunia akademik untuk mampu meneropong perkembangan dan dinamika hukum islam secara menyeluruh, sehingga hukum Islam tidak dinilai sebagai fikih yang stagnan akan tetapi berperan sebagai hukum agama yang rahmatan lil alamin dan supel pada setiap waktu dan zaman.

\footnotetext{
${ }^{2}$ Lihat, Cik Hasan Bisri, KHI dan Peradilan Agama dalam Sistem Hukum Nasional (Cet. 1 ; Logos Wacana Ilmu : Jakarta, 1999), h. 2

${ }^{3}$ Lihat, Abdul Gani Abdullah, Pengantar KHI dalam Tata Hukum Indonesia (Cet. 1 ; Jakarta : Gema Insani Press, 1999), h. 25
} 


\section{Sejarah dan Dinamika Legislasi Hukum Islam Berdasarkan KHI}

Potret sejarah legislasi hukum islam di Indonesia sebenarnya dapat dibaca mulai dari masuknya islam ke nusantara, secara sosiologis dan cultural, hukum islam telah menyatu dan menjadi hukum yang hidup. Akulturasinya dengan tradisi terkadang melahirkan sikap ekstrim dibeberapa daerah, seperti Aceh, Sulawesi Selatan, Minangkabau, Riau dan Padang, hukum islam diterima tanpa reserve, sederajat dengan hukum adat setempat, hal ini dapat dibuktikan dengan adanya pepatah yang mengatakan Adat bersendi syara', syara' bersendi kitabbulah dan syara mengata, adat memakai, yang keduanya merefleksikan bagaimana kental dan menyatunya hubungan antara hukum islam dengan adat setempat. Sifat fleksibel dan elastis yang dimiliki hukum islam inilah yang sebenarnya memungkinkan semuanya terjadi, termasuk proses melakukan legislasi hukum Islam di bidang hukum keluarga.

Dinamika secara umum di atas tergambar secara jelas dalam proses pelaksanaan legislasi hukum Islam di bidang hukum keluarga yang terjadi di Indonesia selama ini. Salah satu diantaranya adalah dinamika legislasi hukum islam yang tergambar dalam sejarah lahirnya Instruksi Presiden Republik Indonesia Nomor 1 Tahun 1991 tentang KHI. Sejumlah kajian dan penelitian menjelaskan bahwa KHI (KHI) mengandung dalam dirinya berbagai potensi kritik. Kritik umumnya diarahkan selain pada eksistensi KHI juga pada substansi hukumnya yang dipandang tidak lagi memadai dalam menyelesaikan pelbagai problem keumatan yang cukup kompleks. Ini karena konstruksi KHI sejak awal kelahirannya telah membawa pelbagai kelemahan. Hasil-hasil penelitian baik berupa tesis maupun disertasi menyatakan bahwa KHI memiliki kelemahan pokok justru pada rumusan visi dan misinya. Terang benderang, beberapa pasal di dalam KHI secara prinsipil berseberangan dengan prinsip-prinsip dasar Islam yang universal, seperti prinsip persamaan (al-musâwah), persaudaraan (al-ikhâ'), dan keadilan (al-`adl), serta gagasan dasar bagi pembentukan masyarakat madani, seperti pluralisme, kesetaraan gender, HAM, demokrasi, dan egalitarianisme. Di samping itu juga disinyalir oleh para pakar hukum, di dalam KHI terdapat sejumlah ketentuan yang tidak lagi sesuai dengan hukumhukum nasional dan konvensi internasional yang telah disepakati bersama. Belum lagi kalau ditelaah dari sudut metodologi, corak hukum KHI masih mengesankan replika hukum dari produk fikih jerih payah ulama zaman lampau. Konstruksi hukum KHI belum dikerangkakan sepenuhnya dalam sudut pandang masyarakat Islam Indonesia, melainkan lebih mencerminkan penyesuaian-penyesuaian dari fikih Timur Tengah dan dunia Arab lainnya.

KHI yang diharapkan adalah seperangkat ketentuan hukum Islam yang senantiasa menjadi rujukan dasar bagi terciptanya masyarakat berkeadilan, yang menjunjung nilainilai kemanusiaan, menghargai hak-hak kaum perempuan, meratanya nuansa kerahmatan dan kebijaksanaan, serta terwujudnya kemaslahatan bagi seluruh umat manusia. Semua ketentuan tersebut hendak digali dan dirumuskan dari sumber-sumber Islam yang otoritatif, al-Qur'ân dan al-Sunnah, melalui pengkajian terhadap kebutuhan, pengalaman, dan ketentuan-ketentuan yang hidup dalam masyarakat Indonesia, khazanah intelektual klasik Islam, dan pengalaman peradaban masyarakat Muslim dan Barat di belahan dunia yang lain. ${ }^{4}$

Perumusan KHI secara substansial dilakukan dengan mengacu kepada sumber hukum Islam, yakni al-Qur'an dan Sunnah Rasulullah, dan secara hirarki mengacu

\footnotetext{
${ }^{4}$ Lihat, Tim Ditbinbanpera, Berbagai Pandangan Terhadap KHI (Cet. 1 ; Jakarta : Yayasan Al-
} Hikmah, 1993), h. 9 - 11 
kepada peraturan perundang-undangan yang berlaku di Negara Kesatuan Republik Indonesia (NKRI). Di samping itu, para perumus KHI memperhatikan perkembangan yang berlaku secara global serta memperhatikan tatanan hukum Barat tertulis (terutama hukum Eropa Kontinental) dan tatanan hukum adat, yang memiliki titik temu dengan tatanan hukum Islam. Berkenaan dengan hal itu, dalam beberapa hal, maka terjadi adaptasi dan modifikasi tatanan hukum lainnya itu ke dalam KHI. Dengan demikian, KHI merupakan suatu perwujudan hukum Islam yang khas di Indonesia.

Hukum Islam adalah hukum yang dibangun berdasarkan pemahaman manusia atas nash al-Qur'an maupun As-Sunnah untuk mengatur kehidupan manusia yang berlaku secara universal-relevan pada setiap zaman (waktu) dan Makan (ruang) manusia. Keuniversalan hukum Islam ini sebagai kelanjutan langsung dari hakekat Islam sebagai agama universal, yakni agama yang substansi - substansi ajaran-Nya tidak dibatasi oleh ruang dan waktu manusia, melainkan berlaku bagi semua orang Islam di mana pun, kapan pun, dan kebangsaan apa pun. T.M. Hasbi Ash-Shidieqy mengutip pendapat Syeikh Mahmud Syaltut sebagaimana diungkapkan oleh Arso Sosroatmodjo dan A. Wasit Aulawi, bahwa syari'at atau hukum islam adalah hukum-hukum dan tata aturan yang ditetapkan Allah buat hamba-Nya untuk diikuti dan dilaksanakan dalam hubungannya dengan Allah dan hubungan manusia sesamanya yang bersumber dari AlQur'an dan Rasul-Nya, Ijma' sahabat dan Ijtihad dengan perantara qias, qarienah, tandatanda dan dalil-dalil. ${ }^{5}$ Penetapan hukum Islam mempunyai herarki, yaitu yang paling utama merujuk Al-Qur'an, kemudian Sunnah, Ijma dan Qiyas. Dalam konteks hukum modern pun herarki yang paling puncak adalah berdasarkan ketuhanan. Hal ini diungkapkan oleh Thomas Aquinas, Thomas Aquinas menentukan posisi hukum kodrat dalam struktur hirarki hukum. Pertama, Puncak dari herarki adalah hukum abadi, yaitu pengaturan rasional atas segala sesuatu di mana Tuhan yang menjadi penguasa alam semesta. Kedua, di bawah hukum abadi adalah hukum kodrat, tidak lain adalah partisipasi makhluk rasional di dalam hukum abadi. Ketiga, di bawah kodrat adalah hukum positif atau hukum buatan manusia.

Penerapan hukum Islam di Indonesia, dalam proses pengambilan keputusan di pengadilan itu selalu menjadi masalah. Selain itu, dari aspek kemajemukan masyarakat bangsa, hukum yang berlaku juga sebaiknya menganut sistem hukum nasional yang bersifat majemuk (pluralistic). Secara teoritik orang selalu mengaitkan berlakunya hukum dengan kekuasaan terutama sekali kekuasaan negara. Indonesia bukannya sebuah negara Islam tetapi sebuah negara nasional yang tidak memberi tempat pada umat Islam untuk melaksanakan hukum Islam, tetapi juga pada umat-umat agama yang lain. Hukum Islam menempati posisi sangat strategis bukan saja bagi umat islam indonesia tetapi bagi dunai Islam pada umumnya dan sekaligus juga menempati posisi strategis dalam sistem hukum Indonesia, untuk dapat berlakunya hukum Islam di Indonesia dalam bingkai sistem hukum nasional diperlukan hukum yang jelas dan dilaksnakan baik oleh para aparat penegak hukum ataupun oleh masyarakat. Untuk itu munculah gagasan dasar KHI (bingkai sistem hukum nasional) untuk menjembatani penerapan hukum Islam di Indonesia.

Penetapan kebijakan hukum di Indonesia, pemerintahan telah menjadikan hukum Islam sebagai bagian dari hukum nasional. Tetapi persoalan kemudian muncul, yaitu

\footnotetext{
${ }^{5}$ Arso Sosroatmodjo dan A. Wasit Aulawi, Hukum Perkawinan di Indonesia (Cet. 2 ; Jakarta : Bulan Bintang, 1978), h. 97 - 98
} 
bagaimana memahami serta melaksanakan hukum Islam dalam konteks hukum nasional atau memasukkan hukum Islam sebagai bagian dari hukum nasional. Permasalahan ini menyebabkan polarisasi tentang proses legislasi hukum Islam ada dua pendapat. Pendapat pertama, bahwa antara agama dan negara perlu ada pemishan secara tegas. Pendapat kedua, bahwa hukum Islam menjadi bagian dari hukum nasional baik simbol maupun substansi. Akhir-akhir ini yang kemudian berhasil memunculkan UU tentang Perbankan Syari'ah. ${ }^{6}$ Untuk melihat gambaran umum hukum islam sebagai bagian hukum nasional, perlu mengikuti dan memahami proses perumusan KHI (KHI). Untuk mendeskripsikan proses perumusan KHI, tidak terlepas pada latar belakang KHI, Landasan Yuridis dan Landasan Fungsional.

\section{Latar Belakang KHI.}

Ide kompilasi hukum muncul sesudah beberapa tahun Mahkamah Agung membina bidang tekhnis yustisial Peradilan Agama. Tugas pembinaan dimaksud, didasari oleh Undang-Undang No. 14 Tahun 1970 tentang ketentuan Pokok Kekuasaan Kehakiman. Pasal 11 ayat (1) undang-undang tersebut menyatakan bahwa organisasi, administrasi, dan keuangan pengadilan dilakukan oleh departemen masing-masing, sedangkan pembinaan teknis yustisial dilakukan oleh mahkamah Agung. Meskipun undang-undang tersebut ditetapkan tahun 1970, tetapi pelaksanaannya di lingkungan peradilan agama pada tahun 1983, yaitu sesudah pendatangan Suras Keputusan Bersama (SKB) Ketua Mahkamah Agung dengan menteri Agama RI No. 01, 02, 03, dan 04/SK/11983 dan No.1,2,3, dan 4 tahun 1983. Keempat SKB dimaksud, adalah jalan pintas sambil menunggu keluarnya Undang-Undang tentang Susunan, Kekuasaan dan Acara pada Peradilan Agama yang menjadi peraturan pelaksanaan Undang-Undang No. 14 tahun 1970 bagi lingkungan Peradilan Agama yang pada saat itu masih sedang dalam proses penyusunan yang intensif (sekarang Undang-Undang Nomor 4 Tahun 2004). Sehinga sesuai dengan fungsi Mahkamah Agung RI terhadap jalannya peradilan di semua lingkungan peradilan agama perlu mengadakan KHI yang selama ini menjadikan hukum positif di Pengadilan Agama.

\section{Landasan Yuridis.}

Landasan yuridis mengenai perlunya hakim memperhatikan kesadaran hukum masyarakat adalah Undang-Undang No. 4 Tahun 2004 Pasal 28 ayat 1 yang berbunyi: " Hakim wajib menggali, mengikuti, dan memahami nilai-nilai hukum dan rasa keadilan yang hidup dalam masyarakat". Selain itu, Fikih Islam mengungkapkan kaidah:" Hukum Islam dapat berubah karena perubahan waktu, tempat, dan keadaan". Keadaan masyarakat itu selalu berkembang karena menggunakan metode yang sangat memperhatikan rasa keadilan masyarakat. Diantara metode itu ialah maslahat mursalah, istihsan, istishab, dan urf. ${ }^{8}$

\section{Landasan fungsional.}

KHI adalah fikih Indonesia karena ia disusun dengan memperhatikan kondisi kebutuhan hukum umat Islam Indonesia. Fikih Indonesia dimaksud adalah fikih yang telah dicetuskan oleh Hazairin dan T.M. Hasbi Ash-Shiddiqi. Fikih sebelumnya mempunyai tipe fikih lokal semacam fikih Hijazy, fikih Mishry, fikih Hindy, fikih lainlain yang sangat mempehatikan kebutuhan dan kesadaran hukum masyarakat setempat. Ia mengarah kepada unifikasi mazhab dalam hukum islam. Oleh karena itu, di dalam sistem

\footnotetext{
${ }^{6}$ Lihat, Arso Sosroatmodjo dan A. Wasit Aulawi, h. 97 - 98

${ }^{7}$ Lihat, Tim Ditbinbanpera, h. 9 - 11

${ }^{8}$ Lihat, Tim Ditbinbanpera, h. 9 .
} 
hukum di Indonesia ini merupakan bentuk terdekat dengan kodifikasi hukum yang menjadi arah pembangunan hukum nasional di Indonesia. ${ }^{9}$

\section{Penerapan KHI dan Aspek - Aspek Pembaharuannya}

Dalam perspektif sejarah, hukum Islam di Indonesia dari masa ke masa tidak menunjukkan perkembangan yang signifikan, bahkan dalam beberapa kajian akademik menyebutkan bahwa hukum Islam di Indonesia menunjukkan kondisi yang stagnan (jalan di tempat), bahkan mengalami kemunduran apabila dianalisis berdasarkan perkembangan peradaban manusia islam modern. Demikian pula adanya dengan kehadiran KHI, yang apabila dikaji secara mendalam tidak lagi memiliki fungsi sebagai institusi yang memenuhi dan menjawab kebutuhan umat islam yang hidup di tengah perkembangan masyarakat global. Dalam perjalanan memerankan fungsinya selama kurang lebih dua (2) dekade terakhir, KHI tidak mampu menunjukkan jati diri sebagai sebuah produk hukum yang mampu bertahan pada setiap waktu dan zamannya. Hal ini tidak terlepas dari sejarah keberadaannya sendiri yang dipandang berseberangan dengan prinsip-prinsip dasar Islam yang universal, seperti prinsip persamaan (al-musâwah), persaudaraan (al$i k h \hat{a})$, dan keadilan $\left(a l^{-}{ }^{\prime} a d l\right)$, serta gagasan dasar bagi pembentukan masyarakat madani, seperti pluralisme, kesetaraan gender, HAM, demokrasi, dan egalitarianism.

\section{Aspek Konstitusional}

Keberadaan KHI di indonesia ini di samping memiliki segi positif juga menimbulkan problematika sendiri. Usaha pemeirntah indonesia membawa substansi hukum islam yang sakralistik itu ke dalam KHI ternyata masih berjumpa dengan anggapan desakralisasi kitab fiqih melalui pembukaan bahan artifisial seperti KHI. Di samping itu dasar hukum KHI yang hanya berupa instruksi presiden (Inpres) membawa permasalahan tersendiri dalam sistem perundang-undangan di indonesia, walaupun dalam prakteknya para hakim pengadilan agama akan menggunakan ketentuan KHI sebagai salah satu dasar hukum dan putusannya tanpa mempersalahkan KHI itu dasarnya hanya berupa Inpres.

Dari sudut lingkup makna the ideal law, kehadiran KHI merupakan rangkaian sejarah hukum nasional yang dapat mengungkapkan ragam makna kehidupan masyarakat Islam Indonesia, terutama tentang : (1) adanya norma hukum yang hidup dan ikut serta bahkan mengatur interaksi sosial, (2) aktualnya dimensi normatif akibata terjadinya ekplanasi fungsional ajaran Islam yan mendorong terpenuhinya tuntutan kebutuhan hukum, (3) responsi struktural yang dini melahirkan rangsangan KHI, dan (4) Alim Ulama Indonesia mengantisipasi ketiga hal di atas dengan kesepakatan bahwa KHI adalah rumusan tertulis hukum Islam yang hidup seiring dengan kondisi hukum dan masyarakat Indonesia. ${ }^{10}$

KHI hadir dalam hukum Indonesia melalui intrumen hukum Inpres No. 1 Tahun 1991 tangggal 10 Juni 1991, dan diantisipasi secara organik oleh keputusan Menteri Agama nomor 154 Tahun 1991 anggal 22 Juli 1991. Terpilihnya Inpres menunjukkan fenomena tata hukum yang dilematis, pada satu segi, pengalaman implementasi program legislatif nasional memper ihatkan Inpres berkemampuan mandiri ntuk berlaku efektif di samping instrumen hukum lainnya dan karenanya memiliki daya atur dalam hukum positif nasional ; dan pada segi lain inpres tidak terlihat sebagai salah satu instrumen dalam tata urutan peraturan perundangan. Sekalipun demikian Inpres - KHI termasuk

\footnotetext{
${ }^{9}$ Lihat, Tim Ditbinbanpera, h. 9

${ }^{10}$ Cik Hasan Bisri, KHI dan Peradilan Agama dalam Sistem Hukum Nasional (Cet. 1 ; Jakarta : Logos Wacana Ilmu , 1999), h. 22
} 
lingkup makna organik pasal 4 ayat 1 UUD 1945 dan berambat pada konvensi produk tradisi konstitsional dalam rangkaian penyelenggaraan negara. ${ }^{11}$

Sekurang-kurangnya tiga (3) hal yang dapat diketahui dari Inpres No 1 Tahun 1991 dan Keputusan Menteri Agama Nomor 154 Tahun 1991, yakni : (1) Perintah menyebarluaskan KHI tidak lain daripada kewajiban masyarakat Islam dalam rangka memfungsionalisasikan eksplanasi ajaran Islam sepanjang yang normatif sebagai hukum yang hidup, (2) Rumusan hukum dalam KHI berupaya mengakhiri persepsi ganda dari keberlakuan hukum Islam yang ditunjuk oleh Pasal 2 ayat 1 serta 2 UU Nomor 1 Tahun 1974, segi hukum formal di dalam Undang - Undang nomor 7 Tahun 1989 sebagai hukum yang diberlakukan secara sempurna, (3) menunjukkan secara tegas wilayah berlaku pada instansi pemerintah dan masyarakat yang memerlukannya. Ketiga hal tersebut bukan saja menunjukkan pentinnya penyebarluasan KHI, tetapi justeru presentasi hukum perkawinan, kewarisan dan wakaf dari KHI menjadi sebuah fenomena sejarah hukum terhadap eksistensi teori hukum yang menyinggung hukum Islam. Masih dijumpai kelompok masyarakat Islam yang menempatkan hukum Islam yang tertulis dalam kitab-kitab fikih sebagai sesuatu yang sakral akibat kedudukannya sebagai bagian dari ajaran Islam. Ia bersama hukum produk legislatif nasional ikut serta dan mengatur interaksi sosial, tetapi di tengah kebersamaan demikian, nilai sakral yang dilekatkan pada hukum Islam menjadi hambatan peletakkan hukum produk legislatif nasional pada kedudukannya yang sederajat dengannya, sekalipun ajaran Islam telah tertransformasi secara formal ke dalamnya. ${ }^{12}$

KHI disusun atas prakarsa penguasa negara dalam hal ini ketua Mahkamah Agung dan Menteri Agama (melalui SKB) dan mendapat pengakuan ulama dari berbagai unsur. Secara resmi KHI merupakan hasil konsensus (ijma') ulama dari berbagai "golongan" melalui media lokakarya yang dilaksanakan secara nasional yang kemudian mendapat legalisasi dari kekuasaan negara yaitu Presiden. Penyusunan KHI dapat dipandang sebagai suatu proses transformasi hukum Islam dalam bentuk tidak tertulis ke dalam peraturan perundang-undangan. Dalam penyusunannya dapat dirinci pada dua tahapan, yaitu Pertama tahapan pengumpulan bahan baku yang digali dari berbagai sumber baik tertulis maupun tidak tertulis. Kedua, tahapan perumusan yang didasarkan kepada peraturan perundang-undangan yang berlaku dan sumber hukum Islam (al-Qur'an dan Sunnah Rasul) khusunya ayat dan teks yang berhubungan dengan substansi KHI. ${ }^{13}$

Dalam penyusunan KHI, para perumusnya memperhatikan perkembangan yang berlaku secara global serta memperhatikan tatanan hukum barat tertulis (terutama hukum eropa continental) dan tatanan hukum adat yang memiliki titik temu dengan tatanan hukum Islam. Berkenaan dengan hal itu, dalam beberapa hal, maka terjadi adaptasi dan modifikasi tatanan hukum lainnya itu ke dalam KHI. Dengan demikian, KHI merupakan suatu perwujudan hukum Islam yang khas Indonesia. Atau dengan kata lain, KHI merupakan wujud hukum Islam yang bercorak keindonesiaan. ${ }^{14}$

Berkenaan dengan kedudukan KHI dalam sistem hukum nasional, hal tersebut diukur oleh unsur-unsur sistem hukum nasional sebagaimana telah dikemukakan. Pertama, landasan ideal dan konstitusional KHI adalah Pancasila dan UUD 1945. Hal itu

11 Abdul Gani Abdullah, Pengantar KHI dalam Tata Hukum Indonesia (Cet. 1 ; Jakarta : Gema Insani Press, 1994), h. 62

${ }^{12}$ Lihat, Abdul Gani Abdullah, h. 63

${ }^{13}$ Lihat, Cik Hasan Bisri, h. 8

${ }^{14}$ Baca, Cik Hasan Bisri, h. 9 
dimuat dalam konsideran Inpres dan dalam penjelasan Umum KHI. Ia disusun sebagai bagian dari sistem hukum nasional yang menjamin kelangsungan hidup beragama berdasarkan Ketuhanan Yang Maha Esa yang sekaligus merupakan perwujudan kesadaran hukum masyarakat dan bangsa Indonesia. Kedua, ia dilegalisasi oleh instrumen hukum dalam bentuk Inpres yang dilakukan oleh keputusan Menteri Agama, yang merupakan bagian dari rangkaian peraturan perundang-undangan yang berlaku. Ketiga, ia dirumuskan dari tatanan hukum Islam yang bersumber dari al-Qur'an dan Sunnah Rasul. Hal itu yang menjadi inti hukum Islam yang mencakup berbagai dimensi : syari'ah, fiqih, fatwa, qanun, idarah, qadha, dan adat. Ia merupakan perwujudan hukum Islam yang bercorak keindonesiaan. Keempat, saluran dalam aktualisasi KHI antara lain pengadilan dalam lingkungan peradilan agama, sebagaimana dapat ditafsirkan secara teologis dari penjelasan umum KHI. ${ }^{15}$

Sesuai dengan tema utama KHI yaitu mempositifkan hukum Islam di Indonesia artinya mempositifkan hukum Islam secara terumus dan sistematik dalam kitab hukum, maka terdapat beberapa sasaran pokok yang hendak dicapai dan dituju, yaitu : 1) Melengkapi pilar Peradilan Agama ; 2) Menyamakan persepsi penerapan hukum ; 3) Mempercepat proses taqribi Baynal Ummah (perbedaan antara ummat Islam) dan 4) Menyingkirkan paham private affairs (Kepentingan Pribadi). ${ }^{16}$

Menurut Abdul Gani Abdullah, dilihat dari tata hukum nasional, KHI dihadapkan pada dua (2) pandangan ; Pertama, sebagai hukum tidak tertulis seperti yang ditunjukkan oleh penggunaan instrmen hukum berupa Inpres yang tidak termasuk dalam rangkaian tata urutan peraturan perundangan yang menjadi sumber hukum tertulis. Kelemahan pandangan ini terletak pada pengabdian terhadap beberapa sumber pengambilan bagi penyusunan buku I, II dan III KHI yang terdiri dari Undang-Undang Nomor 22 tahun 1946 jo UU Nomor 32 Tahun 1954. UU nomor 1 Tahun 1974 jo PP nomor 9 Tahun 1975, PP Nomor 28 tahun 1977. Sumber-sumber tersebut yang justeru mengakrabkan KHI menjadi hukum tertulis. Buku II cenderung mendukung pendapat ini sekalipun dalam kenyatannya ia juga disusun dengan mengambil kaidah hukum dari yurisprodensi Indonesia sepanjang mengenai kewarisan Islam. Kedua, KHI dapat dikategorikan sebagai hukum tertulis. Sumber yang ditunjukkan sebagaimana tersebut di atas menunjukkan KHI berisi law dan rule yang pada gilirannya terangkat menjadi law dengan potensi political power. Inpres nomor 1 tahun 1991 dipandang sebagai salah satu produk political power yang mengalirkan KHI dalam jajaran law. Melalui Inpres Nomor 1 tahun 1991 pada saatnya akan membuktikan bahwa manusia dipandang mampu mengantisipasi kebutuhan hukumnya seperti dalam semboyan The living law daripada sekedar mengklaim adanya the ideal law tanpa akhir. ${ }^{17}$

Dilihat dari sejarah pembentukannya, KHI merupakan jalan pintas untuk mengisi kekosongan hukum materil di peradilan agama yang mengakibatkan disparitas putusanputusan pengadilan agama selama ini. Hal itu terjadi disebabkan tidak adanya kitab hukum yang positif dan unifikatif. Berppedoman pada ungkapan 'tak ada rotan, akarpun jadi', maka selama belum diwujudkan cita-cita memiliki hukum positif undang-undang perdata Islam melalui jalur formal ketatanegaraan, untuk sementara cukupkan saja dalam bentuk kompilasi. Pengukuhan formalnya berupa Inpres, sedangkan pernyataan berlakunya dalam bentuk keputusan menteri agama nomor 154 tahun 1991. Terhadap

\footnotetext{
${ }^{15}$ Cik Hasan Bisri, h. 10

${ }^{16}$ Lihat, Cik Hasan Bisri, h. 27 - 35.

${ }^{17}$ Lihat, Abdul Gani Abdullah, h. 64
} 
kenyaan ini, bagi mereka yang bersikap kaku dan formalistis wujud kelahiran KHI dianggap kurang memenuhi syarat perundang-undangan. Akan tetapi bagi mereka yang berpandangan dari sudut sosiologis, tidak demikian halnya, karena menurut ajaran sosiologi hukum, hukum adalah kebutuhan masyarakat. Dalam satu ajaran hukum dipahami bahwa "hukum adalah pakaian masyarakat yang harus sesuai ukuran dan jahitannya dengan kebutuhan masyarakat". Jika ajaran ini dikaitkan dengan teori realisme atau teori fungsional tidak mesti suatu perangkat hukum harus dicipta secara kaku menurut hukum tata negara dalam bentuk undang-undang. Karena bukan hanya apa yang dirumuskan dalam bentuk undang-undang yang bernilai sebagai hukum positif dan obyektif, akan tetapi suatu perangkat hukum yang dirumuskan dalam bentuk lain, asal nilai-nilainya benar-benar sesuai dengan kebutuhan masyarakat dan cocok pula untuk dipakai oleh masyarakat yang bersangkutan, mempunyai validitas dan otoritas sebagai hukum untuk mengayomi ketertiban hidup masyarakat.

Dengan demikian, meskipun bentuk formal KHI hanya didukung dalam bentuk Inpres, tidak mengurangi sifat legalitas dan otoritasnya. Karena segala yang dirumuskan di dalamnya benar-benar sangat dibutuhkan untuk ketertiban masyarakat Islam masa kini dan masa akan datang. Kandungan isinyapun secara sungguh-sungguh telah diupayakan agara benar-benar sesuai dengan keinginan dan kesadaran masyarakat pemakainya.

Dalam berbagai peraturan perundang-undangan yang mengatur mengenai tata urutan peraturan perundangan sejak tahun 1966 sampai tahun 2003, jenis Inpres tidak secara eksplisit diatur di dalamnya. Misalnya, dalam TAP MPRS Tahun 1966 walaupun secara eksplisit dimuat berbagai ketetapan yang berisi norma hukum, baik yang bersifat mengatur (regeling) maupun yang bersifat menetapkan (beschikking) termasuk diantaranya yang berupa instruksi menteri, namun TAP MPRS tersebut tidak memuat jenis Inpres. Namun demikian, bisa saja sebenarnya Inpres merupakan salah satu jenis produk hukum yang diatur dalam TAP MPRS tersebut. Hal ini dapat disimpulkan dari frase "dan lain-lain" yang ada dalam TAP MPRS tersebut. Frase "dan lain-lain" membuka kemungkinan jenis peraturan perundang-undangan yang lain dapat masuk dalam tata urutan peraturan perundangan tersebut.

Dalam praktek yang sering terjadi adalah bahwa Inpres, sesuai dengan namanya, memang dimaksudkan untuk memberikan intruksi atau arahan kepada institusi atau lembaga yang ada di bawahnya. Hal ini dapat dilihat dari format yang terdapat dalam Inpres yang biasanya menunjuk dengan sangat jelas dan limitatif siapa yang diberikan arahan. Namun demikian, norma yang dikandung dalam Inpres tersebut dapat terjadi bahwa Inpres yang diterbitkan pada masa itu berisi norma yang bersifat abstrak, umum, dan berlaku terus menerus atau dengan kata lain berisi norma yang bersifat perundangundangan. Namun juga, tidak menutup kemungkinan norma yang dimuat bersifat individual, konkret dan sekali selesai atau norma yang bersifat penetapan.

Pada masa berlakunya TAP MPR nomor 3 tahun 2000, Inpres secara jelas TIDAK diatur dalam tata urutan peraturan perundang-undangan. Hal ini setidaknya dapat dilihat dari ketentuan pasal 2. Namun apabila dilihat dari ketentuan selanjutnya ternyata terdapat klausula yang bersifat terbuka yang memberi kemungkinan peraturan perundangundangan yang tidak terdapat dalam tata urutan peraturan perundang-undangan tersebut dapat dikategorikan sebagai peraturan perundang-undangan sepanjang tidak bertentangan dengan peraturan yang lebih tinggi tingkatannya. ${ }^{18}$

\footnotetext{
${ }^{18}$ Lihat, Abdul Gani Abdullah, h. $68-74$
} 
Pada masa berlakunya UU No.10 Tahun 2004, Inpres juga tidak dimuat sebagai salah satu jenis peraturan perundang-undangan yang tercantum dalam tata urutan peraturan perundang-undangan. Namun, seperti yang terdapat dalam TAP MPR Nomor 3 tahun 2000, dalam UU Nomor 10 tahun 2004 terdapat klausula yang mengakui jenis peraturan perundang-undangan lain yang tidak terdapat dalam tata urutan tersebut dapat dikategorikan sebagai peraturan perundang-undangan asalkan peraturan perundangundangan tersebut diperintahkan oleh peraturan perundang-undangan yang lebih tinggi.

Berkaitan dengan hal tersebut dapat disimpulkan bahwa kedudukan Inpres dalam sistem peraturan perundang-undangan dari masa ke masa cukup dinamis. Hal ini setidaknya terlihat pada TAP MPRS Nomor XX/MPRS/1966 yang walaupun tidak secara eksplisit memuat Inpres di dalamnya namun dalam tata urutan ini terdapat jenis Instruksi menteri. Hal ini logis apabila Inpres kemudia merupakan salah satu jenis dari peraturan perundang-undangan tersebut. Selain itu, dimungkinkan jenis produk hukum lain yang tidak tercantum dalam tata urutan tersebut merupakan salah satu jenis peraturan perundang-undangan termasuk Inpres di dalamnya. ${ }^{19}$ Berbeda dengan jenis tata urutan peraturan perundang-undangan yang ada setelahnya. Dalam TAP MPR No. III Tahun 2000 maupun UU No. 10 Tahun 2004, Inpres tidak disinggung sama sekali dalam kedua peraturan perundang-undangan tersebut. Hal ini dikarenakan dalam kedua peraturan perundang-undangan tersebut Inpres tidak dimaksudkan sebagai salah satu bentuk peraturan perundang-undangan, namun lebih merupakan Intruksi atau araha Presiden terhadap bawahannya.

Jadi dapat disimpulkan bahwa setelah berlakunya UU Nomor 10 tahun 2004 bentuk hukum Inpres tidak dimaksudkan sebagai peraturan perundang-undangan, karena Inpres lebih bersifat arahan atau perintah oleh presiden kepada bawahannya yang bersifat tekhnis. Namun demikian tidak menutup kemungkinan dengan adanya klausula terbuka seperti yang terdapat dalam pasal 7 ayat (2) berserta penjelasannya, maka dimungkinkan Inpres termasuk di dalamnya. Hal ini dikarenakan penggunakan frase "... antara lain..." dalam penjelasan pasal 7 untuk menjelaskan bentuk peraturan perundang-undangan yang lain yang tidak terdapat dalam tata urutan peraturan perundang-undangan. Hanya saja dalam kajian akademik, menurut hemat penulis, nilai-nilai kontroversial tersebut di atas telah menempatkan posisi KHI sebagai produk hukum yang mengandung problematik, sehingga berpeluang atau paling tidak patut dipikirkan untuk dilakukan perubahanperubahan menuju kesempurnaannya.

\section{Aspek Content (Materi / Isi dan Gagasan)}

Pengaturan mengenai tata urutan peraturan perundang-undangan yang saat ini berlaku terdapat dalam UU No. 10 Tahun 2004. Dalam UU inipun pengaturan mengenai tata urutan dan jenis peraturan perundang-undangan juga tidak sepenuhnya menyebut jenis peraturan perundang-undangan yang ada dalam praktek ketatanegaraan Indonesia saat ini.

Selanjutnya, dalam konteks sistem hukum Indonesia, peradilan agama merupakan salah satu lingkungan peradilan yang diakui eksistensinya di Indonesia dan memiliki kedudukan yang sederajat dengan peradilan lainnya berdasarkan undang-undang nomor 14 tahun 1970 tentang ketenuan-ketentuan pokok kekuasaan kehakiman. Sebagai landasan yuridisnya, peradilan agama diatur lebih lanjut dalam undang-undang nomor 7 tahun 1989 tentang peradilan agama sebagaimana telah dirubah dan di tambah berdasarkan undang-undang nomor 3 tahun 2006 tentang perubahan atas undang-undang

\footnotetext{
${ }^{19}$ Lihat, Abdul Gani Abdullah, h. 79
} 
nomor tahun 1989 tentang peradilan agama, jo. Undang-undang nomor 50 tahun 2009 tentang perubahan kedua atas undang-undang nomor 7 tahun 1989 tentang peradilan agama.

Peradilan agama merupakan peradilan khusus karena peradilan agama hanya menyelesaikan perkara-perkara tertentu dan bagi golongan rakyat tertentu. Golongan rakyat tertentu disini maksudnya adalah orang-orang yang beragama islam, termasuk orang atau badan hukum yang menundukkan diri dengan suka rela pada hukum islam tentang hal-hal yang menjadi kewenangan pengadilan agama. Adapun perkara-perkara tertentu yang menjadi kewenangan pengadilan agama berdasarkan pasal 49 undangundang nomor 3 tahun 2006 meliputi :a. Perkawinan, b. Waris, c. Wasiat, d. Hibah, e. Wakaf, f. Zakat, g. Infaq, h. shadakah, dan i. Ekonomi syariah.

Untuk menyelesaikan perkara-perkara tersebut diperlukan sumber hukum materil sebagai dasar hukum penyelesainnya. Dalam hukum islam, ada 3 sumber hukum yang pokok, yaitu: Al-Qur'an, Al-hadist dan ar-Ra'yu, yaitu akal manusia yang memenuhi syarat untuk berijtihad. Ketentuan hukum yang ada dalam Al-qur'an dan hadist sering disebut syariat. Syariat ini bersifat mujmal atau global, sehingga sulit untuk langsung di aplikasikan dalam kehidupan sehari-hari. Untuk itu diperlukan penafsiran dan perincian lebih lanjut sehingga mudah di peraktekkan dalam kehidupan sehari-hari. Hal ini dilakukan dengan ilmu fiqih. Fiqih di sini mempunyai 2 pengertian, yaitu, pertama, sebagai ilmu yang mendalami dan membahas syariat untuk kemudian dijabarkan dalam ketentuan yang lebih sistematis dan terperinci sehingga mudah diaplikasikan dalam praktek. Kedua, fiqih juga berarti aturan hukum yang dihasilkan oleh ijtihad manusia (dalam hal ini para mujtahid), sehingga di sini sudah ada keterlibatan akal di dalamnya. Sebagai hasil ijtihad manusia maka fiqih ini mempunyai sifat tidak abadi, dalam arti bisa berubah sejalan dengan perubahan tempat dan waktu. Selain itu, fiqih ini jumlahnya tidak hanya satu. Di kalangan ahlus sunnah wal jamaah (sunni) sendiri ada empat madzhab besar yang masing-masing memiliki kitab fiqih sendiri, yaitu madzhab hanafi, madzhab maliki, madzhab syafi'i dan madzhab hambali. ${ }^{20}$

Di lingkungan peradilan agama sendiri, ada tiga belas buah kitab fiqih yang kesemuanya bermazhab syafi'i sebagai sumber hukum materil untuk menyelesaikan perkara yang di ajukan ke pengadilan agama (lihat surat edaran biro peradilan agama tanggal 18 februari 1958 nomor B/I/735). Adanya keanekaragaman kitab fiqih sebagai sumber hukum untuk memutuskan perkara di pengadilan agama berimplikasi terhadap kemungkinan terjadinya perbedaan putusan atau disparitas antara pengadilan agama lainnya untuk perkara yang sama. Hal ini tentunya kurang mendukung untuk terwujudnya kepastian hukum bagi umat islam di indonesia. Hal ini menjadi salah satu alasan untuk di lakukannya unifikasi hukum islam khususnya di bidang hukum keluarga. Untuk maksud tersebut di keluarkanlah KHI yang terdiri dari tiga buku (yaitu buku I tentang perkawinan, buku II tentang kewarisan, dan buku III tantang wakaf) berdasarkan intruksi presiden nomor 1 tahun 1991. KHI di susun dan dirumuskan untuk mengisi kekosongan hukum substansial, yang di berlakukan pada pengadilan dalam lingkungan peradilan agama. Dengan diberlakukannya KHI, secara yuridis hukum islam di bidang perkawinan, kewarisan,dan perwakafan menjadi hukum positif tertulis dalam sistem hukum nasional (tata hukum indonesia) ia menjadi dasar untuk pengambilan keputusan hukum terhadap perkara-perkara yang diajukan ke pengadilan dalam lingkungan peradilan agama.

${ }^{20}$ Lihat, Tim Ditbinbanpera, h. 15 
Menurut hemat penulis, kondisi ini juga sekaligus memberikan gambaran atas kelemahan KHI sebagai kitab material hukum Islam yang bersifat tertulis dan kompilatif, di mana tidak secara kompilatif mengatur segala materi yang menjadi kewenangan peradilan agama sebagaimana diatur dalam UU Nomor 50 Tahun 2009.

\section{Aspek Penegakan Hukum Islam (rule of law) dalam bingkai Keindonesiaan.}

Satu segi dari proses penegakan hukum yang baik adalah segi pelaksanaan hukum atau penegakan hukum yang biasa juga diistilahkan dengan Law Enforcement. Sebaikbaik materi peraturan, hukum tidak akan bermanfaat kalau segi penegakannya tidak sesuai dengan kaidah-kaidah penegakan hukum yang benar. KHI sebagi bagian dari keseluruhan tata hukum Islam, sudah dapat ditegakkan dan dipaksakan nilai-nilainya bagi masyarakat Islam Indonesia melalui kewenangan lingkungan Peradilan Agama. Semua hakim yang berfungsi di lingkungan peradilan agama dan rujukan hukum mesti mereka pedoman sama di seluruh Indonesia yakni KHI sebagai satu-satunya kitab hukum yang memiliki keabsahan dan otoritas.

Penegakan Hukum Islam dideskripsikan dengan realisasi KHI. Pembentukan KHI merupakan penjabaran dari pasal 49 Undang-Undang N0. 7 Tahun 1989 tentang peradilan Agama. Pasal 49 dimaksud, memerlukan kodifikasi dan unifikasi hukum yang memadai, untuk mewujudkan kesadaran masyarakat mengenai pelaksanaan hukum islam di bidang perkawinan, kewarisan, wasiat, hibah, shadaqah, dan wakaf. Oleh karena itu, penyusunan KHI secara resmi melalui Yurisprudensi, dalam Keputusan Bersama Ketua Mahkamah Agung RI dan Menteri Agama RI No. 07/KMA/1985 dan No.25 Tahun 1985 tanggal 25 Maret 1985. ${ }^{21}$

KHI disusun dan dirumuskan dalam kitab hukum sebagai tata hukum Islam yang berbentuk positif dan unifikatif. Semua lapisan masyarakat Islam dipaksa tunduk mentaatinya. Pelaksanaan dan penerapannya tidak lagi diserahkan atas kehendak pemeluknya, tetapi ditunjuk seperangkat jajaran penguasa dan instansi negara sebagai aparat pengawas dan pelaksanaan penerapannya. Dengan adanya seperangkat jajaran penguasa dan instansi kekuasaan negara yang ikut campur mengawasi pelaksanaannya, sepanjang hal-hal yang mnyangkut bidang perkawinan, hibah, wasiat, wakaf, dan warisan, telah diangkat sebagai aturan yang menyangkut ketertiban umum.

Dengan demikian, kelahiran KHI sebagi hukum positif dan unifikatif, maka praktik private affairs disingkirkan. Sejak KHI lahir dimulai sejarah baru di Indonesia, yang mengangkat derajat penerapan hukum Islam sebagai hukum perdata yang resmi dan bersifat publik yang dapat dipaksakan penerapannya oleh alat kekuasaan negara, terutama oleh Badan Peradilan Agama. Adanya pemerataan ke arah paham yang menempatkan hukum Islam yang diatur dalam KHI sebagai hukum perdata yang resmi dan positif, yang memiliki sanksi dan dapat dipaksakan oleh alat kekuasaan negara, sungguh masih berat dan cenderung membutuhkan political will serta kesadaran yang optimal pada institusi negara yang berkuasa dan berwenang. Hal ini pula yang menciptakan kondisi di mana masih banyak dijumpai kasus perceraian (talak) liar di luar pengadilan, poligami illegal, perkawinan di bawah tangan dan hal-hal yang lain dilakukan tidak melalui prosedur hukum Islam yang berlaku di Indonesia.

\section{Simpulan}

Berdasarkan gambaran uraian penelitian di atas, maka sebagai intisari sekaligus sebagai jawaban akhir dari problematika penelitian ini, penulis dapat menarik simpulan

${ }^{21}$ Baca : Zainuddin Ali, Hukum Islam : Pengantar Ilmu Hukum Islam di Indonesia (Cet. 1 ; Jakarta : Sinar Grafika, 2006), h. 100 
bahwa: Berdasarkan sejarah kelahirannya, KHI hadir sebagai pemenuhan kebutuhan masyarakat Islam sekaligus mengisi kekosongan yang terjadi pada Lembaga Peradilan Agama yang kewenangannya diatur dalam UU No. 7 Tahun 1989. Namun dalam perjalannya, sejumlah kajian dan penelitian menjelaskan bahwa KHI mengandung berbagai potensi kritik, di mana KHI dipandang tidak lagi memadai dalam menyelesaikan pelbagai problem keumatan yang cukup kompleks. Ini karena konstruksi KHI sejak awal kelahirannya telah membawa pelbagai kelemahan, diantaranya pada rumusan visi dan misinya yang secara prinsipil berseberangan dengan prinsip-prinsip dasar Islam yang universal, seperti prinsip persamaan (al-musâwah), persaudaraan (al-ikhâ'), dan keadilan $\left(a l\right.$ - $\left.^{\prime} a d l\right)$, serta gagasan dasar bagi pembentukan masyarakat madani, seperti pluralisme, kesetaraan gender, HAM, demokrasi, dan egalitarianisme.

Beberapa aspek yang dipandang sebagai problematika KHI untuk dilakukan perubahan adalah :

Aspek Konstitusional, Dilihat dari tata hukum nasional, KHI dihadapkan pada dua pandangan; Pertama, sebagai hukum tidak tertulis seperti yang ditunjukkan oleh penggunaan instrmen hukum berupa Inpres yang tidak termasuk dalam rangkaian tata urutan peraturan perundangan yang menjadi sumber hukum tertulis. Kedua, KHI dapat dikategorikan sebagai hukum tertulis dan diterima ditengah masyarakat karena sesuai dengan kebutuhannya. Posisi kontroversial tersebut menempatkan posisi KHI sebagai produk hukum yang mengandung problematik, sehingga berpeluang untuk dilakukan perubahan-perubahan di dalamnya.

Aspek Content (Materi / Isi dan Gagasan), Kehadiran KHI sebagai pemenuhan kebutuhan hukum materil pada Peradilan Agama memberikan gambaran atas kelemahan KHI sebagai kitab material hukum Islam yang bersifat tertulis dan kompilatif, di mana tidak secara kompilatif mengatur segala materi yang menjadi kewenangan peradilan agama sebagaimana diatur dalam undang-undang nomor 7 tahun 1989 tentang peradilan agama sebagaimana telah dirubah dan di tambah berdasarkan undang-undang nomor 3 tahun 2006 tentang perubahan atas undang-undang nomor tahun 1989 tentang peradilan agama, jo. Undang-undang nomor 50 tahun 2009 tentang perubahan kedua atas undangundang nomor 7 tahun 1989 tentang peradilan agama, khususnya yang diatur dalam pasal 49 yang meliputi : Perkawinan, Waris, Wasiat, Hibah, Wakaf, Zakat, Infaq, shadakah, dan Ekonomi syariah.

Aspek Penegakan Hukum Islam (rule of law) dalam bingkai Keindonesiaan. Dalam konteks penegakkan hukum, KHI sebagai hukum perdata yang resmi dan positif, harus memiliki sanksi yang dapat dipaksakan oleh alat kekuasaan Negara. Namun pada kenyataannya hal ini masih sangat berat dan terabaikan sehingga masih banyak dijumpai kasus-kasus yang diatur dalam KHI dilakukan tidak melalui prosedur hukum Islam yang berlaku di Indonesia.

\section{Daftar Pustaka}

Abdullah, Abdul Gani, Pengantar KHI dalam Tata Hukum Indonesia Cet. 1 ; Jakarta : Gema Insani Press, 1994

Abdurahman, KHI di Indonesia , Jakarta: Akademika Pressindo,1992. 
Ali , Zainuddin, Hukum Islam : Pengantar Ilmu Hukum Islam di Indonesia , Jakarta: Sinar Grafika, 2006.

Ali, Muhammd Daud, Hukum Islam, Pengantar Ilmu Hukum dan Tata Hukum Islam di Indonesia Cet. 1 ; Jakarta : Rajawali Pers, 1996.

Amrullah, Ahmad,dkk. Dimensi Hukum Islam dalam Sistem Hukum Nasional, Jakarta: Gema Insani Press, 1999.

Arif, Abd Salam, Pembaruan Pemikiran Hukum Islam Antara Fakta dan Realita: Kajian Pemikiran Hukum Syaikh Mahmud Syaltut, Yogyakarta: LESFI, 2003.

Arifin, Busthanul, Pelembagaan Hukum Islam di Indonesia: Akar Sejarah, Hambatan dan Prospeknya, Jakarta: Gema Insani Press, 1996.

Bisri, Cik Hasan, et.al., KHI dan Peradilan Agama di Indonesia , jakarta: Logos Wacana Ilmu, 1999.

Bisri, Cik Hasan, KHI dan Peradilan Agama dalam Sistem Hukum Nasional Cet. 1 ; Jakarta : Logos Wacana Ilmu , 1999

Fuad, Mahsun, Hukum Islam Indonesia - Dari Nalar Partispatoris Hingga Emansipatoris, Cet. 1 ; LkiS : Yogyakarta, 2005

Hasan, Muhammad Tholhah, Islam dalam Perspektif Sosial Kultural , Jakarta: Lantabora Press, 2004.

Sosroatmodjo, Arso dan A. Wasit Aulawi, Hukum Perkawinan di Indonesia Cet. 2 ; Jakarta : Bulan Bintang, 1978.

Tim Ditbinbanpera, Berbagai Pandangan Terhadap KHI Cet. 1 ; Jakarta : Yayasan AlHikmah, 1993. 